\title{
ВПЛИВ МОДУЛЯТОРІВ NМDА-РЕЦЕПТОРІВ НА БІОХІМІЧНІ ЗМІНИ В СІТКІВЦІ ПРИ ІШЕМІЧНОМУ ТА ТРАВМАТИЧНОМУ УРАЖЕННІ ЗОРОВОГО АНАЛІЗАТОРА
}

Вступ. Глутаматна ексайтотоксичність і гіперактивація NMDA-рецепторів відіграють провідну роль в ураженні зорового аналізатора ішемічного та травматичного генезу. Залишається невивченим вплив модуляторів різних сайтів NMDA-рецепторів на метаболічні процеси в сітківці ока за цих патологічних станів.

Мета дослідження - встановити вплив модуляторів NMDA-рецепторів амантадину та мемантину на біохімічні зміни (оксидативний стрес, енергодефріцит, стан системи оксиду азоту, вміст глутамату) в сітківці за ішемічного ураження зорового аналізатора в щурів і травматичного ураження зорового аналізатора у кролів.

Методи дослідження. Досліди проведено на 56 білих щурах-самцях та 24 кролях. Ішемічне ураження зорового аналізатора в щурів моделювали шляхом створення однобічної ішемії-репероузії в басейні a. ophthalmica. Травматичне ураження зорового аналізатора у кролів викликали дією потоку вуглекислого газу під тиском на рогівку ока. Модулятори NMDA-рецепторів вводили впродовж 7 діб до та через 30 хв після моделювання патології. Застосовували блокатор поліамінового сайта амантадин (5 мг/кг внутрішньовенно) та блокатор френциклідинового сайта мемантин (20 мг/кг внутрішньошлунково). Визначали вміст аденозинтрифросфорної кислоти, маркери оксидативно-нітрозативного стресу, рівень глутамату в сітківці ока, рівень нейронспецифрічної енолази в сироватці крові.

Результати й обговорення. Застосування інгібіторів NMDA-рецепторів викликало деескалацію рівня нейронспецифрічної енолази в крові, зменшувало енергодефріцит, оксидативно-нітрозативний стрес, рівень глутамату в сітківці за ішемії-реперфузії ока в щурів та контузії ока у кролів. Інгібітор поліамінового сайта амантадин перевершував (в 1,2-1,5 раза, p<0,05) інгібітор френциклідинового сайта мемантин за здатністю коригувати рівень аденозинтрифосфрорної кислоти, малонового діальдегіду, окисномодифрікованих протеїнів, відновлювати активність глутатіонпероксидази в сітківці за ішемічного та травматичного ураження зорового аналізатора.

Висновки. Модулятори поліамінового та френциклідинового сайтів NMDA-рецепторів проявляли нейроретинопротекторний ефрект як за ішемічного, так і за травматичного ураження зорового аналізатора у тварин. Вивчення впливу амантадину на репаративні процеси в сітківці ока є перспективним напрямком подальших досліджень.

КЛЮЧОВІ СЛОВА: зоровий аналізатор; NMDA-рецептори; амантадин; мемантин; ішемія; контузія.

ВСТУП. Глутаматна ексайтотоксичність відіграє провідну роль в ураженні зорового аналізатора при ішемії, глаукомі [1], вторинній альтерації сітківки на тлі хірургічних втручань $[2,3]$. Підвищення рівня глутамату та гіперактивація NMDA-рецепторів призводять до ушкодження гангліонарних клітин сітківки внаслідок ініціації оксидативного стресу, апоптозу, запальної реакції $[4,5]$. Зазначені процеси являють собою провідний напрямок, у колі якого $€$ сенс впроваджувати заходи, спрямовані на реалізацію засад первинної нейроретинопротекторної терапії. В окремих роботах засвідчено, що інгібітор (с) В. Л. Повх, 2018.
NMDA-рецепторів мемантин справляє нейропротекторний есрект при експериментальному ураженні сітківки ока $[6,7]$. Тому доцільним $€$ дослідження впливу модуляторів різних сайтів NMDA-рецепторів на біохімічні зміни в сітківці за ішемічного та травматичного ураження зорового аналізатора.

Мета дослідження - встановити вплив модуляторів NMDA-рецепторів амантадину та мемантину на біохімічні зміни (оксидативний стрес, енергодефіцит, стан системи оксиду азоту, вміст глутамату) в сітківці за ішемічного ураження зорового аналізатора в щурів і травматичного ураження зорового аналізатора у кролів. 
МЕТОДИ ДОСЛІДЖЕННЯ. Досліди проведено на 56 білих лабораторних щурах-самцях лінії Вістар масою 160-190 г та 24 кролях-самцях породи Шиншила масою 3,0-3,9 кг. Тварини перебували в стандартних умовах віварію Вінницького національного медичного університету імені М. І. Пирогова, воду і корм отримували аd libitum. Ïх поділили на групи по 6-7 особин у кожній. Під час роботи з тваринами дотримано рекомендацій Державного фрармакологічного центру МОЗ України і біоетичних норм відповідно до Першого національного конгресу України 3 біоетики (Київ, 2001), положень Європейської конвенції про захист хребетних тварин, що використовуються для дослідних та інших наукових цілей (Страсбург, 1986), Закону України від 21.02.2006 р. № 3447-IV “Про захист тварин від жорстокого поводження", що засвідчила комісія з біоетики Вінницького національного медичного університету імені М. І. Пирогова (протокол № 8 від 10.09.2016р.). Будь-які травматичні маніпуляції та евтаназію тварин проводили за умов пропофролового наркозу (60 мг/кг внутрішньочеревно).

Ішемічне ураження зорового аналізатора в щурів моделювали шляхом створення однобічної ішемії-реперфузії (IP) в басейні a. ophthalmica, яку викликали, накладаючи ретробульбарну лігатуру на ліве око тварини із затягуванням до зникнення кровотоку на 60 хв. Потім ретробульбарні лігатури обережно знімали, і кровообіг у басейні a. ophthalmica відновлювався. Контролем слугувала група псевдооперованих щурів, яким накладали ретробульбарні лігатури без наступного затягування. Модулятори NMDA-рецепторів вводили впродовж 7 діб (1 раз на добу) до та через 30 хв після накладання ретробульбарної лігатури на а. ophthalmica. Травматичне ураження зорового аналізатора у кролів викликали дією потоку вуглекислого газу під тиском, що створювали за допомогою пневматичного пістолета [8]. Як модулятори NMDA-рецепторів застосовували блокатор поліамінового сайта амантадин у дозі 5 мг/кг внутрішньовенно та блокатор фенциклідинового сайта мемантин у дозі 20 мг/кг внутрішньошлунково. Групи тварин з контрольною патологією (без лікування) отримували лише 0,9 \% розчин $\mathrm{NaCl}$ внутрішньовенно $з$ розрахунку 2 мл/кг.

Через 24 год після моделювання патології проводили енуклеацію, очні яблука промивали охолодженим $1,15 \%$ розчином $\mathrm{KCl}\left(4-8{ }^{\circ} \mathrm{C}\right)$, позбавляли кон'юнктиви та м'язів, за допомогою мікрохірургічного інструментарію видаляли передній відділ ока і кришталик, залишок надрізали, розправляли так, щоб було видно очне дно, і видаляли ділянки сітківки. Сітківку гомогенізу- вали протягом 1-2 хв в охолодженому середовищі $1,15 \% \mathrm{KCl}$ (у співвідношенні маса/об'єм 1:4) при 3000 об./хв. Центрифуугували 30 хв при 600 g, відбирали аліквоти пост'ядерного супернатанту в мікропробірки Еппендорф і до проведення досліджень зберігали при $-20^{\circ} \mathrm{C}$.

У гомогенатах сітківки ока визначали вміст малонового діальдегіду (МДА) за реакцією з тіобарбітуровою кислотою [9], карбонільних груп протеїнів (КГП) - за реакцією з 2,4-динітрофренілгідразином [10]. Рівень загального білка визначали мікробіуретовим методом [11], активність глутатіонпероксидази (ГПО; КФ 1.11.1.9) спектрофотометричним методом за накопиченням окисненого глутатіону [12], сумарний вміст нітритів та нітратів - за реакцією з реактивом Грісса після відновлення нітратів зависсю цинкового порошку в розчині амоніаку [13], вміст аденозинтрифоссрорної кислоти (АТФ) у свіжовиготовленому безбілковому трихлороцтовому екстракті сітківки 1:10 (10\% розчин трихлороцтової кислоти) - методом тонкошарової хроматограсрії [14], вміст глутамату - методом тонкошарової хроматограсрії [15]. У сироватці крові визначали вміст маркера нейродеструкції - нейронспецисрічної енолази (NSE; КФ 4.2.1.11) методом ІФА за допомогою набору “NSE ELISAKIT" (DAI, CШA).

Статистичний аналіз проводили 3 використанням t-критерію Стьюдента й U-критерію Манна-Уїтні, зв'язок між показниками визначали шляхом кореляційного аналізу за Пірсоном. Достовірними вважали відмінності при р<0,05.

РЕЗУЛЬТАТИ Й ОБГОВОРЕННЯ. ВСТаНОВлено (табл. 1), що через 24 год після відтворення моделі IP ока в сироватці крові щурів реєструвалось багаторазове (в 11,4 раза, $p<0,05$ ) зростання рівня NSE, що є чутливим та специфічним маркером альтерації нейронів [16]. NSE регулює нейрональну та гліальну активність і за високої концентрації стимулює експресію прозапальних цитокінів, індукує апоптоз [16]. NSE експресується в нейронах сітківки, пігментному епітелії та фороторецепторних клітинах [17]. Отже, зростання цього маркера свідчило про розвиток ішемічного ураження зорового аналізора в щурів. Через 24 год після IP у сітківці ока тварин виявляли ознаки енергодесіциту, оксидативно-нітрозативного стресу, зниження активності антиоксидантної системи на фоні підвищення рівня глутамату. Так, у сітківці ока щурів 2-ї групи (контрольна патологія) рівень АТФ був меншим у 2,42 раза, рівень МДА та КГП - більшим у 2,57 і 2,52 раза, активність ГПО була нижчою в 2,34 раза, вміст метаболітів NO (нітратів та нітритів) був більшим у 3,37 раза, а рівень глутамату - вищим у 2,03 раза, ніж у псевдооперованих тварин 1-ї групи 
$(p<0,01)$. Рівень NSE достовірно корелював 3 рівнем АТФ $(r=-0,62, p<0,05)$, глутамату $(r=0,72$, $p<0,01)$, МДА і метаболітів NO ( $r=0,52 ; 0,51$, $p<0,05)$, але менш тісно асоціювався 3 рівнем КГП та активністю ГПО (r=0,45; -0,46, p=0,1).

Застосування фрармакологічних модуляторів NMDA-рецепторів - інгібітора поліамінового сайта (амантадину) та інгібітора фенциклідинового сайта (мемантину) достовірно зменшувало біохімічні зміни в сітківці ока щурів з ішемічним ураженням зорового аналізатора, що асоціювалось зі зниженням рівня NSE в сироватці крові. Так, використання амантадину та мемантину стримувало розвиток мітохондріальної дисорункції і запобігало зменшенню АТФ у сітківці практично $з$ однаковою ефрективністю: у тварин 3-ї (IP+амантадин) та 4-ї (IP+мемантин) груп рівень АТФ був вищим в 1,66 і 1,50 раза, ніж у щурів 2-ї групи (p<0,05), але залишався нижчим в 1,46 та 1,61 раза, ніж у тварин 1-ї групи ( $<<0,05)$. За умов IP ока застосування модуляторів NMDA-рецепторів викликало деескалацію ознак оксидативно-нітрозативного стресу, сприяло відновленню антиоксидантної активності, зменшенню рівня глутамату, при цьому ефект інгібітора поліамі- нового сайта за окремими показниками був більшим, ніж інгібітора фенциклідинового сайта: в щурів 3-ї групи (IP+амантадин) рівень МДА, КГП, нітратів та нітритів, глутамату був нижчим, активність ГПО була вищою в 2,14; 2,0; 1,83; 1,61 і 1,74 раза, а у тварин 4-ї групи (IP+мемантин) в 1,81; 1,67; 1,64; 1,53 та 1,42 раза відповідно, ніж у щурів 2-ї групи $(p<0,05)$. За умов IP за здатністю коригувати рівень МДА, КГП, активність ГПО, знижувати рівень NSE амантадин достовірно перевершував мемантин - у середньому в $1,2-1,5$ раза $(p<0,05)$.

Травматичне ураження зорового аналізатора у кролів також характеризувалось значущим збільшенням (у 45,4 раза, p<0,001) рівня NSE в сироватці крові, що асоціювалось зі зменшенням рівня АТФ на фоні зростання ознак оксидативно-нітрозативного стресу і глутаматної ексайтотоксичності в сітківці (табл. 2). Через 24 год після контузії ока в сітківці кролів рівень АТФ був нижчим у 2,09 раза, рівень МДА, КГП, нітритів і нітратів, глутамату - вищим у 2,32; 3,56; 3,23 та 2,02 раза, активність ГПО була нижчою в 1,88 раза, ніж у інтактних тварин. Застосування амантадину та мемантину забезпечувало деескала-

Таблиця 1 - Вплив модуляторів NMDA-рецепторів на рівень нейронспецифічної енолази в сироватці крові та біохімічні показники сітківки щурів з ішемічним ураженням зорового аналізатора $(\mathrm{M} \pm \mathrm{m}, \mathrm{n}=7)$

\begin{tabular}{|c|c|c|c|c|}
\hline \multirow{3}{*}{ Показник } & \multicolumn{4}{|c|}{ Група щурів } \\
\hline & псевдооперовані & $\mathrm{IP}+0,9 \% \mathrm{NaCl}$ & IP+амантадин & IP+мемантин \\
\hline & 1-ша & $2-г а$ & 3-тя & 4-та \\
\hline NSE, нг/МЛ & $0,31 \pm 0,013$ & $3,52 \pm 0,15^{\star \star}$ & $0,58 \pm 0,06$ & $1,27 \pm 0,04^{\star * \wedge}$ \\
\hline \multicolumn{5}{|c|}{ Біохімічні показники сітківки ока } \\
\hline АТФ, нмоль/мг протеїну & $58,7 \pm 1,33$ & $24,2 \pm 1,20^{\star \star}$ & $40,1 \pm 1,45^{\text {*\# }}$ & $36,4 \pm 1,05^{\star \#}$ \\
\hline МДА, нмоль/мг протеїну & $4,35 \pm 0,19$ & $11,2 \pm 0,95^{\star \star}$ & $5,24 \pm 0,26^{\star \#}$ & $6,18 \pm 0,23^{\star \#^{\wedge}}$ \\
\hline КГП, нмоль/мг протеїну & $2,05 \pm 0,08$ & $5,18 \pm 0,08^{\star \star}$ & $2,60 \pm 0,10^{\star *}$ & $3,10 \pm 0,12^{\star \#^{\wedge}}$ \\
\hline ГПО, мкмоль/хв на 1 мг протеїну & $7,25 \pm 0,33$ & $3,10 \pm 0,19^{* *}$ & $5,40 \pm 0,26^{\star *}$ & $4,43 \pm 0,19^{\star \#^{\wedge}}$ \\
\hline Нітрити+нітрати, нмоль/мг протеїну & $6,25 \pm 0,31$ & $21,1 \pm 0,79^{\star \star}$ & $11,5 \pm 0,51^{\text {*\# }}$ & $12,9 \pm 0,64^{\star \#}$ \\
\hline Глутамат, нмоль/мг протеїну & $7,68 \pm 0,37$ & $15,6 \pm 0,92^{\star \star}$ & $9,70 \pm 0,65^{\star \#}$ & $10,2 \pm 0,31^{\text {*\# }}$ \\
\hline
\end{tabular}

Примітки. Тут і в таблиці 2:

1. * - достовірність відмінностей відносно 1-ї групи (* $-p<0,05$; ** $-p<0,01)$.

2. * - достовірність відмінностей відносно 2-ї групи $(p<0,05)$.

3. ^ - достовірність відмінностей відносно 3-ї групи $(p<0,05)$.

Таблиця 2 - Вплив модуляторів NMDA-рецепторів на рівень нейронспецифічної енолази в сироватці крові та біохімічні показники сітківки кролів 3 травматичним ураженням зорового аналізатора $(\mathrm{M} \pm \mathrm{m}, \mathrm{n}=6)$

\begin{tabular}{|c|c|c|c|c|}
\hline \multirow{3}{*}{ Показник } & \multicolumn{4}{|c|}{ Група тварин } \\
\hline & інтактні & $\begin{array}{c}\text { контузія ока+ } \\
0,9 \% \mathrm{NaCl}\end{array}$ & $\begin{array}{c}\text { контузія ока+ } \\
\text { амантадин }\end{array}$ & $\begin{array}{c}\text { контузія ока+ } \\
\text { мемантин }\end{array}$ \\
\hline & 1-ша & 2-га & 3-тя & 4-та \\
\hline NSE, нг/MЛ & $0,33 \pm 0,03$ & $15,0 \pm 0,45^{\star \star}$ & $7,64 \pm 0,33^{\star \#}$ & $10,1 \pm 0,26^{\star \#^{\wedge}}$ \\
\hline \multicolumn{5}{|c|}{ Біохімічні показники сітківки ока } \\
\hline АТФ, нмоль/мг протеїну & $53,4 \pm 1,94$ & $25,5 \pm 1,87^{\star \star}$ & $40,2 \pm 1,56^{\star \#}$ & $34,4 \pm 1,16^{\star \#^{\wedge}}$ \\
\hline МДА, нмоль/мг протеїну & $3,62 \pm 0,22$ & $8,40 \pm 0,16^{\star \star}$ & $4,59 \pm 0,26^{\star \#}$ & $5,85 \pm 0,20^{\star \#^{\wedge}}$ \\
\hline КГП, нмоль/мг протеїну & $1,11 \pm 0,08$ & $3,96 \pm 0,08^{\star \star}$ & $1,34 \pm 0,17^{\star \#}$ & $2,01 \pm 0,07^{\star \#^{\wedge}}$ \\
\hline ГПО, мкмоль/хв на 1 мг протеїну & $6,23 \pm 0,28$ & $3,31 \pm 0,27^{\star *}$ & $4,91 \pm 0,14^{\star \#}$ & $4,03 \pm 0,14^{\star \#^{\wedge}}$ \\
\hline Нітрити+нітрати, нмоль/мг протеїну & $5,85 \pm 0,28$ & $18,9 \pm 0,82^{\star \star}$ & $10,4 \pm 0,20^{\star \#}$ & $11,3 \pm 0,63^{\star \#}$ \\
\hline Глутамат, нмоль/мг протеїну & $8,18 \pm 0,36$ & $16,5 \pm 0,89^{\star \star}$ & $9,89 \pm 0,55^{\star \#}$ & $10,8 \pm 0,29^{* \#}$ \\
\hline
\end{tabular}


цію (в 1,96 та 1,48 раза) рівня NSE в сироватці крові, що асоціювалось зі зменшенням біохімічних змін у сітківці кролів із травматичним ураженням зорового аналізатора. При цьому амантадин більш ефективно стримував розвиток енергодефріциту та оксидативного стресу, ніж мемантин, і зіставлявся з ним за здатністю коригувати рівень метаболітів NO та глутамату.

Таким чином, модулятори поліамінового та френциклідинового сайтів NMDA-рецепторів проявляли достовірний нейроретинопротекторний ефект як за ішемічного, так і за травматичного ураження зорового аналізатора у тварин.

ВИСНОВКИ. 1. Ішемічне ураження зорового аналізатора характеризується зростанням рівня NSE в сироватці крові (в 11,4 раза), що супроводжується розвитком енергодефріциту, оксидативно-нітрозативного стресу, зниженням антиоксидантної активності, підвищенням рівня глутама- ту в сітківці ока щурів. За травматичного ураження зорового аналізатора виявляють більш виразні ознаки нейроретинодеструкції, енергодеоріциту, оксидативно-нітрозативного стресу та глутаматної ексайтотоксичності.

2. Застосування модуляторів NMDA-рецепторів зменшує біохімічні зміни в сітківці ока за ішемічного та травматичного ураження зорового аналізатора. При цьому амантадин (5 мг/кг внутрішньовенно) перевершує мемантин (20 мг/кг внутрішньошлунково) в 1,2-1,5 раза $(p<0,05)$ за здатністю коригувати енергодефіцит, пригнічувати активність процесів ліпопероксидації та окисної модисрікації протеїнів, відновлювати активність глутатіонпероксидази. Амантадин зіставляється з мемантином за здатністю коригувати рівень метаболітів NO та зменшувати рівень глутамату в сітківці ока за ішемічного та травматичного ураження зорового аналізатора у тварин.

\section{СПИСОК ЛІТЕРАТУРИ}

1. Invulnerability of retinal ganglion cells to NMDA excitotoxicity / E.M. Ullian, W. B. Barkis, S. Chen [et al.] // Mol. Cell Neurosci. - 2004. - 26, No. 4. - P. 544-557.

2. Glutamate-induced excitotoxicity in retina: neuroprotection with receptor antagonist, dextromethorphan, but not with calcium channel blockers / J. I. Calzada B. E. Jones, P. A. Netland, D. A. Johnson // Neurochem. Res. - 2002. - 27, No. 1-2. - P. 79-88.

3. Lomerizine, a $\mathrm{Ca}^{2+}$ channel blocker, protects against neuronal degeneration within the visual center of the brain after retinal damage in mice / Y. Ito, S. Nakamura, H. Tanaka [et al.] // CNS Neurosci. Ther. - 2010. 16, No. 2. - P. 103-114.

4. Expression of $\mathrm{N}$-methyl-d-aspartate receptor 1 in rats with chronic ocular hypertension / J. H. Kim, N. Y. Lee, S. W. Jung, C. K. Park // Neuroscience. - 2007. - 149, No. 4. - P. 908-916.

5. Involvement of calpain/p35-p25/Cdk5/NMDAR signaling pathway in glutamate-induced neurotoxicity in cultured rat retinal neurons / Y. Miao, L. D. Dong, J. Chen [et al.] // PLoS One. - 2012. - 7, No. 8. - P. 42318.

6. Neuroprotective effect of memantine in different retinal injury models in rats / E. WoldeMussie, E. Yoles, M. Schwartz [et al.] // J. Glaucoma. - 2002. - 11, No. 6. P. 474-480.

7. Abdel-Hamid A. A. Effect of memantine: A NMDA receptor blocker, on ethambutol-induced retinal injury / A. A. Abdel-Hamid, Ael-D. Firgany, E. M. Ali // Ann. Anat. 2016. - 204. - P. 86-92.

8. Пат. на корисну модель 109789 Україна, МПК A61F 9/00. Спосіб моделювання контузії ока для скринінгової оцінки нейроретинопротективної активності лікарських засобів та біологічно активних речовин / Черешнюк І. Л., Комнацька К. М., Повх В. Л., Ходаківський О. А. ; заявники та патентовласники Черешнюк І. Л., Комнацька К. М., Повх В. Л., Ходаків- ський О. А. - № u 201601524 ; заявл. 19.02.16 ; опубл. 12.09.16, Бюл. № 17.

9. Владимиров Ю. В. Перекисное окисление липидов в биологических мембранах / Ю. В. Владимиров, А. И. Арчаков. - М. : Наука, 1972. - 252 с.

10. Заічко Н. В. Окислювальна модисрікація білків сироватки крові як маркер активності ревматоїдного артриту та ії зміни під впливом фрармакотерапії амізоном, індометацином, німесулідом / Н. В. Заічко // Вісн. Вінниц. держ. мед. ун-ту. - 2003. - № 7 (2/2). C. 664-666.

11. Кочетов Г. А. Практическое руководство по энзимологии / Г. А. Кочетов. - М. : Высшая школа, 1980. -272 c.

12. Власова С. Н. Активность глутатион-зависимых ферментов эритроцитов при хронических заболеваниях печени у детей / С. Н. Власова, Е.И.Шабунина, И. А. Перслегина // Лаб. дело. - 1990. - № 8. C. 19-22.

13. Коренман И. М. Методы определения органических соединений / И. М. Коренман. - М. : Химия, 1975. - 360 c.

14. Прохорова М. И. Современные методы биохимических исследований / М. И. Прохорова. - Л. : Изд-во Ленинград. ун-та, 1982. - 272 с.

15. Попова Л. Д. Вплив кінуренової кислоти на вміст збуджувальних і гальмівних медіаторів у щурів із різним рівнем судомної готовності / Л. Д. Попова // Укр. біохім. журн. - 2006. - 78, № 5. - С. 120-126.

16. Neuron specific enolase: a promising therapeutic target in acute spinal cord injury / A. Haque, S. K. Ray, A. Cox, N. L. Banik // Metabolic Brain Disease. - 2016. 31, No. 3. - P. 487-495.

17. Fujieda $H$. Expression of neuron-specific enolase in the developing rat retina as revealed by immunocytochemistry / H. Fujieda, T. Sato, K. Wake // Brain Res. Dev. Brain Res. - 1994. - 82, No. 1-2. - P. 69-80. 


\section{REFERENCES}

1. Ullian, E.M., Barkis, W.B., Chen, S., Diamond, J.S., \& Barres, B.A. (2004). Invulnerability of retinal ganglion cells to NMDA excitotoxicity. Mol. Cell Neurosci, 26 (4), 544-557.

2. Calzada, J.I., Jones, B.E., Netland, P.A., \& Johnson, D.A. (2002). Glutamate-induced excitotoxicity in retina: neuroprotection with receptor antagonist, dextromethorphan, but not with calcium channel blockers. Neurochem. Res., 27, 1-2, 79-88.

3. Ito, Y., Nakamura, S., Tanaka, H., Tsuruma, K., Shimazawa, M., Araie, M., \& Hara H. (2010). Lomerizine, $\mathrm{a} \mathrm{Ca}^{2+}$ channel blocker, protects against neuronal degeneration within the visual center of the brain after retinal damage in mice. CNS Neurosci. Ther., 6 (2),103-114. http://doi.org/10.1111/j.1755-5949.2009.00081.x

4. Kim, J.H., Lee, N.Y., Jung, S.W., \& Park C.K. (2007). Expression of $\mathrm{N}$-methyl-d-aspartate receptor 1 in rats with chronic ocular hypertension. Neuroscience, 149 (4), 908-916.

5. Miao, Y., Dong, L.D., Chen, J., Hu, X.C., Yang, X.L., \& Wang Z. (2012). Involvement of calpain/p35-p25/Cdk5/ NMDAR signaling pathway in glutamate-induced neurotoxicity in cultured rat retinal neurons. PLoS One, 7 (8), 42318. http://doi.org/10.1371/journal.pone.0042318

6. WoldeMussie, E., Yoles, E., Schwartz, M., Ruiz, G., \& Wheeler, L.A. (2002). Neuroprotective effect of memantine in different retinal injury models in rats. J. Glaucoma, 11 (6), 474-480.

7. Abdel-Hamid, A.A., Firgany, Ael-D., \& Ali, E.M. (2016). Effect of memantine: A NMDA receptor blocker, on ethambutol-induced retinal injury. Ann. Anat., 204, 86-92. http://doi.org/10.1016/j.aanat.2015.11.006.

8. Chereshniuk, I.L., Komnatska, K.M., Povkh, V.L., \& Khodakivskyi, O.A. (2016). Patent for Utility Model No 109789 UA. Kyiv, Ukraine: Ukrainian Intellectual Property Institute [in Ukrainian].

9. Vladimirov, Yu.V., \& Archakov, A.I. (1972). Perekisnoe okislenie lipidov $v$ biologicheskikh membranakh [Peroxide oxidation of lipids in biological membranes]. Moscow: Nauka [in Russian].
10. Zaichko, N.V. (2003). Okysliuvalna modyfikatsiia bilkiv syrovatky krovi yak marker aktyvnosti revmatoidnoho artrytu ta yii zminy pid vplyvom farmakoterapii amizonom, indometatsynom, nimesulidom [Oxidative modification of blood serum proteins as a marker of activity of rheumatoid arthritis and its changes under the influence of pharmacotherapy with amison, indomethacin, nimesulide]. Visnyk Vinnytskoho derzhavnoho medychnoho universytetu Bulletin of Vinnytsia State Medical University, 7 (2/2), 664-666 [in Ukrainian].

11. Kochetov, G.A. (1980) Prakticheskoe rukovodstvo po enzimologii [Practical guide to enzymology]. Moscow: Vysshaya shkola [in Russian].

12. Vlasova, S.N., Shabunina, E.I., \& Perslegina, I.A (1990). Aktivnost glutation-zavisimykh fermentov eritrotsitov pri khronicheskikh zabolevaniyakh pecheni u detey [The activity of glutathione-dependent enzymes of erythrocytes in chronic liver diseases in children]. Laboratornoe delo - Laboratory Work, 8, 19-22 [in Russian].

13. Korenman, I.M. (1975). Metody opredeleniya organicheskikh soyedineniy [Methods for the determination of organic compounds]. Moscow: Khimiya [in Russian].

14. Prokhorova, M.I. (1982). Sovremennye metody biokhimicheskikh issledovaniy [Modern methods of biochemical research]. Leningrad: Izdatelstvo Leningradskogo universiteta [in Russian].

15. Popova, L.D. (2006). Vplyv kinurenovoi kysloty na vmist zbudzhuvalnykh i halmivnykh mediatoriv u shchuriv iz riznym rivnem sudomnoi hotovnosti [Effect of kynurenic acid on the content of excitatory and inhibitory mediators in rats with different levels of seizure readiness]. Ukrainskyi biokhimichnyi zhurnal-Ukrainian Biochemical Journal, 78 (5), 120-126 [in Ukrainian].

16. Haque, A., Ray, S.K., Cox, A., \& Banik, N.L. (2016). Neuron specific enolase: a promising therapeutic target in acute spinal cord injury. Metabolic Brain Disease, 31 (3), 487-495. http://doi.org/10.1007/s11011-016-9801-6.

17. Fujieda, H., Sato, T., \& Wake, K. (1994). Expression of neuron-specific enolase in the developing rat retina as revealed by immunocytochemistry. Brain Res. Dev. Brain Res., 82, 1-2, 69-80.

\section{ВЛИЯНИЕ МОДУЛЯТОРОВ NМDА-РЕЦЕПТОРОВ НА БИОХИМИЧЕСКИЕ ИЗМЕНЕНИЯ В СЕТЧАТКЕ ПРИ ИШЕМИЧЕСКОМ И ТРАВМАТИЧЕСКОМ ПОРАЖЕНИИ ЗРИТЕЛЬНОГО АНАЛИЗАТОРА}

\section{Резюме}

Вступление. Глутаматная эксайтотоксичность и гиперактивация NMDA-рецепторов играют ведущую роль в поражении зрительного анализатора ишемического и травматического генеза. Остается неизученным влияние модуляторов разных сайтов NMDA-рецепторов на метаболические процессы в сетчатке глаза при этих патологических состояниях.

Цель исследования - установить влияние модуляторов NMDA-рецепторов амантадина и мемантина на биохимические изменения (оксидативный стресс, энергодефицит, состояние системы оксида азота, содержание глутамата) в сетчатке при ишемическом поражении зрительного анализатора у крыс и травматическом поражении зрительного анализатора у кроликов. 
Методы исследования. Опыты проведены на 56 белых крысах-самцах и 24 кроликах. Ишемическое поражение зрительного анализатора у крыс моделировали путем создания односторонней ишемии-реперфузии в бассейне а. ophthalmica. Травматическое поражение зрительного анализатора у кроликов вызывали действием потока углекислого газа под давлением на роговицу глаза. Модуляторы NMDA-речепторов вводили в течение 7 дней до и через 30 мин после моделирования патологии. Применяли блокатор полиаминового сайта амантадин (5 мг/кг внутривенно) и блокатор френциклидинового сайта мемантин (20 мг/кг внутрижелудочно). Определяли содержание аденозинтрисросфрорной кислоты, маркеры оксидативно-нитрозативного стресса, уровень глутамата в сетчатке глаза, уровень нейронспецифрической энолазы в сыворотке крови.

Результаты и обсуждение. Применение ингибиторов NMDA-рецепторов вызывало деэскалацию уровня нейронспецифической энолазы в крови, уменьшало энергодефицит, оксидативно-нитрозативный стресс, уровень глутамата в сетчатке при ишемии-реперфузии глаза у крыс и контузии глаза у кроликов. Ингибитор полиаминового сайта амантадин превосходил (в 1,2-1,5 раза, p<0,05) ингибитор френциклидинового сайта мемантин по способности корректировать уровень аденозинтрифосфорной кислоты, малонового диальдегида, окислительномодифицированных протеинов, восстанавливать активность глутатионпероксидазы в сетчатке при ишемическом и травматическом поражении зрительного анализатора.

Выводы. Модуляторы полиаминового и фенциклидинового сайтов NMDA-рецепторов проявляли нейроретинопротекторный эфорект как при ишемическом, так и при травматическом поражении зрительного анализатора у животных. Изучение влияния амантадина на репаративные процессы в сетчатке глаза является перспективным направлением дальнейших исследований.

КЛЮЧЕВЫЕ СЛОВА: зрительный анализатор; NMDA-рецепторы; амантадин; мемантин; ишемия; контузия.

\author{
M. PYROHOV VINNYTSIA NATIONAL MEDICAL UNIVERSITY
}

\title{
INFLUENCE OF NMDA RECEPTOR MODULATORS ON BIOCHEMICAL CHANGES IN RETINA IN CASE OF ISCHEMIA AND TRAUMA OF VISUAL ANALYZER
}

\section{Summary}

Introduction. Glutamate exitotoxicity and hyperactivation of NMDA receptors play an important role in affecting the visual analyzer in cases of ischemia and trauma. It remains unexplored the influence of modulators of various sites of NMDA receptors on metabolic processes in the retina in these pathological conditions.

The aim of the work - to determine the effect of NMDA receptor modulators on metabolic changes (oxidative stress, energy deficit, state of nitrogen oxide system, glutamate content) in the retina with the ischemic injury of the visual analyzer in rats and traumatic damage to the visual analyzer in rabbits.

Research Methods. Experiments were conducted on 56 white male rats and 24 rabbits. Ischemic lesions of the visual analyzer in rats was caused by the creation of a one-sided ischemia-reperfusion in the a. ophthalmica. Traumatic damage of the visual analyzer in rabbits was caused by the action of a carbon dioxide stream under pressure on the cornea of the eye. NMDA receptor modulators were administered within 7 days before and 30 minutes after pathology simulation. Polyamino site blocker amantadine sulfate $(5 \mathrm{mg} / \mathrm{kg} \mathrm{i} / \mathrm{v})$ and phencyclidine site blocker memantine (20 mg/kg i/g) were used. The content of ATP, markers of oxidative-nitrosative stress, glutamate levels in retina, and the level of neuronspecific enolase (NSE) in serum were determined.

Results and Discussion. The use of NMDA receptor inhibitors causes de-escalation of NSE levels in the blood, reduces energy deficit, oxidative-nitrosative stress, glutamate levels in the retina of ischemia-reperfusion of the eye in rats and contusion of the eye in rabbits. The polyamino site inhibitor amantadine sulfate exceeds (in 1.2-1.5 times, $p<0.05)$ the fencyclidine site inhibitor memantine by the ability to adjust the levels of ATP, MDA, oxide-modified proteins, to restore the activity of glutathione peroxidase in the retina on ischemic and traumatic lesions of visual analyzer.

Conclusions. Thus, the modulators of the polyamino- and phencyclidine sites of the NMDA receptors showed a protective effect on neuroretina for both ischemic and traumatic damage of the visual analyzer in animals. The study of the effects of amantadine sulfate on reparative processes in the retina is a promising direction for further research.

KEY WORDS: visual analyzer; NMDA receptor; amantadine; memantine; ischemia; concussion. Вінниця, 21018, Україна, е-mail: biochem@vnmu.edu.ua. 